\title{
Natalizumab wearing-off effect
}

\section{The hunt for the elusive pharmacodynamic biomarker}

John F. Foley, MD, and Olaf Stuve, MD, PhD

Neurol Neuroimmunol Neuroinflamm 2020;7:e706. doi:10.1212/NXI.0000000000000706

Natalizumab is a highly efficacious humanized recombinant antibody against $\alpha 4$-integrin that is approved for relapsing forms of MS. ${ }^{1}$ Regular natalizumab dosing is $300 \mathrm{mg}$ IV every 4 weeks. Roughly one-third of the patients report a wearing-off effect of natalizumab, generally in the last week of their infusion cycle. Wearing-off is predominantly manifest by fatigue and neurogenic pain. Changes in the neurologic examination are infrequent, and a correlation with MRI worsening has not been reported.

Given that natalizumab works by blocking leukocyte access to the brain and spinal cord, a dose effect and consequently a wearing-off phenomenon appear biologically plausible. Very likely, there is a threshold effect for natalizumab efficacy and safety. Higher body weight has previously been shown to correlate with lower receptor occupancy (RO). ${ }^{2}$ The advent of extended interval dosing (EID) for progressive multifocal leukoencephalopathy mitigation has amplified the importance of understanding the relationship between natalizumab efficacy and the wearing-off phenomenon. ${ }^{3}$

In this issue of Neurology ${ }^{\circledR}$ : Neuroimmunology \& Neuroinflammation, Bringeland et al. $^{4}$ categorized patients with relapsing-remitting MS (RMMS) based on their reported wearing-off effect (regular, sometimes, never) and used mass cytometry to compare their natalizumab RO. Specifically, 40 RRMS participants were enrolled in a single center cross-sectional study. Clinical and demographic data including disease characteristics, treatment duration, wearingoff symptoms, age, body mass index (BMI), working status, smoking habits, and vitamin D levels were analyzed. Eight patients (20.0\%) reported regular occurrence of wearing-off symptoms; of interest, these individuals had lower natalizumab RO than patients who reported having such symptoms sometimes or never. A higher BMI was associated with a lower RO. No other demographic or disease characteristics were associated with the wearing-off phenomenon.

Other investigators failed to show a similar association between a4-integrin RO (saturation) and wearing-off symptoms. In a study by van Kempen et al., a total of $32 \%$ of 93 patients on natalizumab reported current symptoms of wearing-off, with 54\% reporting wearing-off symptoms at some point. Surprisingly, the wearing-off effect was more frequently reported in a standard interval group (SID) (39\%) than in an extended interval group (19\%). In addition, the wearing-off effect was not associated with numerous variables, including body weight.

It is challenging to ascertain why these studies from Bringeland et al. ${ }^{4}$ and van Kempen et al. ${ }^{3}$ came to different conclusions regarding the wearing-off phenomena. Although both used validated and custom patient-reported outcomes (PROs) to define wearing-off, the tools used had no commonality. It is conceivable that the use of separate instruments contributed to patient-reported differences in the definition and duration of the wearing-off effect. The timing of PRO administration is not defined in the Bringeland cohort and therefore could be sampling patient experience at differing intervals relative to their infusion.

\begin{abstract}
Correspondence
Dr. Stüve

olaf.stuve@utsouthwestern.edu
\end{abstract}

\section{RELATED ARTICLE}

Wearing-off at the end of natalizumab dosing intervals is associated with low receptor occupancy

Page e678

From the Rocky Mountain Multiple Sclerosis Clinic (J.F.F.), Salt Lake City, UT; Department of Neurology and Neurotherapeutics (O.S.), University of Texas Southwestern Medical Center at Dallas; and Neurology Section (O.S.), VA North Texas Health Care System, Medical Service, Dallas.

Go to Neurology.org/NN for full disclosures. Funding information is provided at the end of the article.

This is an open access article distributed under the terms of the Creative Commons Attribution-NonCommercial-NoDerivatives License 4.0 (CC BY-NC-ND), which permits downloading and sharing the work provided it is properly cited. The work cannot be changed in any way or used commercially without permission from the journal. 
Although Bringeland did not study an EID population, the fact that a higher percentage of wearing-off was seen in the van Kempen SID cohort would make the association between lower RO and wearing-off less likely. An intermediate effect on RO in the Bringeland "sometimes" patient group was also not seen. The small sample size in the Bringeland "regular" group may also be playing a role in these observations. The correlation between lower RO and higher weight groups has been extensively delineated. BMI does tend to follow weight with a similar effect, and hence, higher BMI patients would be expected to have lower RO.

Methodological issues may also explain the differences in study outcomes between the 2 studies, namely, multiparameter flow vs mass cytometric assays that were used. It appears that van Kempen et al. ${ }^{3}$ assessed natalizumab binding to a4-integrin exclusively on CD8 effector memory and effector cells. In their study, experimental samples were compared with saturated reference sample. By contrast, Bringeland et al. ${ }^{4}$ stained all peripheral blood leukocytes. Then, bound natalizumab was detected with an anti-IgG4 antibody, and total a4-integrin was detected with an antiCD49d antibody specific for a different epitope than natalizumab. Indeed, Bringeland et $\mathrm{al}^{4}{ }^{4}$ did determine that wearing-off symptoms were associated with reduced $\mathrm{RO}$ in $\mathrm{CD}^{+}{ }^{+}$and $\mathrm{CD}^{+} \mathrm{T}$ cell subsets before infusion. Both cell types are thought to perpetuate MS disease activity through local proinflammatory effects within the $\mathrm{CNS},{ }^{5-7}$ and both cell types are diminished in the capability to travel to the CNS by natalizumab. ${ }^{8}$

As stated above, natalizumab is a highly effective therapy for patients with active MS. In our opinion, it is unlikely that a standard dosing interval of natalizumab will provide optimal benefits for all recipients. Although the wearing-off effect does not clearly correlate with declining efficacy as defined by increased relapses or MRI associated change, further study to solidify the relationship between the wearing-off phenomenon and pharmacodynamic and pharmacokinetic markers is certainly warranted. The efficacy of EID is currently being evaluated in a clinical trial (clinicaltrials.gov/ct2/show/ NCT03689972). Ultimately, cellular or molecular biomarkers will be necessary to define the optimal natalizumab dose in individual patients.

\section{Study funding}

No targeted funding reported.

\section{Disclosure}

The authors report no relevant disclosures. Go to Neurology. org/NN for full disclosures.

\section{References}

1. Shirani A, Stuve O. Natalizumab: perspectives from the bench to bedside. Cold Spring Harb Perspect Med 2018;8:a029066.

2. Foley JF, Goelz S, Hoyt T, Christensen A, Metzger RR. Evaluation of natalizumab pharmacokinetics and pharmacodynamics with standard and extended interval dosing. Mult Scler Relat Disord 2019;31:65-71.

3. van Kempen ZLE, Doesburg D, Dekker I, et al. The natalizumab wearing-off effect: end of natalizumab cycle, recurrence of MS symptoms. Neurology 2019;93: e1579-e1586.

4. Bringeland G, Blaser N, Myhr KM, Vedeler CA, Gavasso S. Wearing-off at the end of natalizumab dosing intervals is associated with low receptor occupancy. Neurol Neuroimmunol Neuroinflamm 2020;7:e678. 10.1212/NXI.0000000000000678.

5. Ota K, Matsui M, Milford EL, Mackin GA, Weiner HL, Hafler DA. T-cell recognition of an immunodominant myelin basic protein epitope in multiple sclerosis. Nature 1990;346:183-187.

6. Pette M, Fujita K, Wilkinson D, et al. Myelin autoreactivity in multiple sclerosis: recognition of myelin basic protein in the context of HLA-DR2 products by T lymphocytes of multiple-sclerosis patients and healthy donors. Proc Natl Acad Sci USA 1990;87:7968-7972.

7. Babbe H, Roers A, Waisman A, et al. Clonal expansions of CD8(+) T cells dominate the $\mathrm{T}$ cell infiltrate in active multiple sclerosis lesions as shown by micromanipulation and single cell polymerase chain reaction. J Exp Med 2000;192: 393-404.

8. Stuve O, Marra CM, Jerome KR, et al. Immune surveillance in multiple sclerosis patients treated with natalizumab. Ann Neurol 2006;59:743-747. 


\title{
Neurology \\ Neuroimmunology \& Neuroinflammation
}

\author{
Natalizumab wearing-off effect: The hunt for the elusive pharmacodynamic biomarker \\ John F. Foley and Olaf Stuve \\ Neurol Neuroimmunol Neuroinflamm 2020;7; \\ DOI 10.1212/NXI.0000000000000706
}

This information is current as of March 10, 2020

\begin{abstract}
Updated Information \& Services

References

Subspecialty Collections

Permissions \& Licensing

Reprints

including high resolution figures, can be found at: http://nn.neurology.org/content/7/3/e706.full.html

This article cites 8 articles, 4 of which you can access for free at: http://nn.neurology.org/content/7/3/e706.full.html\#\#ref-list-1

This article, along with others on similar topics, appears in the following collection(s):

Multiple sclerosis

http://nn.neurology.org//cgi/collection/multiple_sclerosis

Information about reproducing this article in parts (figures,tables) or in its entirety can be found online at:

http://nn.neurology.org/misc/about.xhtml\#permissions

Information about ordering reprints can be found online: http://nn.neurology.org/misc/addir.xhtml\#reprintsus
\end{abstract}

Neurol Neuroimmunol Neuroinflamm is an official journal of the American Academy of Neurology.

Published since April 2014, it is an open-access, online-only, continuous publication journal. Copyright

Copyright $\odot 2020$ The Author(s). Published by Wolters Kluwer Health, Inc. on behalf of the American Academy of Neurology.. All rights reserved. Online ISSN: 2332-7812.

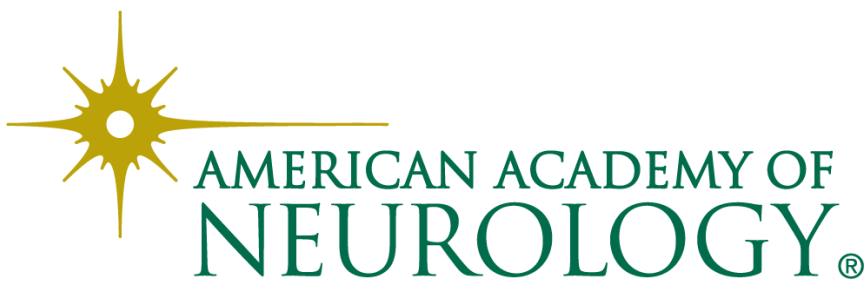

